Zaktad Historii Wychowania,

Wydziat Studiów Edukacyjnych

Uniwersytet im. Adama Mickiewicza w Poznaniu

\title{
Geneza i rozwój szkolnego ustawodawstwa Kościoła w epoce średniowiecza (rekonesans)
}

\begin{abstract}
The genesis and development of Church legislation on education in the Middle Ages
The aim of the article is to present the beginnings and the subsequent development and evolution of church law in the sphere of education from the $4^{\text {th }}$ to the beginning of the $16^{\text {th }}$ century. The roots of the acts of law presented by the Popes, synods and councils were based on the traditions of Roman law, but a variety of reasons from the field of policy, economy and society led to the need to establish a church school system. The aim of the Church was to create an independent school system with its own purposes, different from civil schools.

The article shows the main factors in the development of the legislation in the sphere of education and the functioning of the schools, and the relationship between civil and Church leaders. Another field of analysis is to search for the inspirations, aims and reception of the law in cathedral, collegiate, parish and monastic schools.
\end{abstract}

Keywords: Church law, Education in the Middle Ages

Zagadnienie genezy szkolnego ustawodawstwa Kościoła musi być analizowane w kontekście przemian kulturowych, społecznych, gospodarczych i religijnych, jakie miały miejsce w cesarstwie rzymskim w okresie od drugiej połowy III do okresu panowania cesarza Konstantyna Wielkiego. Pamiętać trzeba, że pierwsze gminy chrześcijańskie, które porzuciły diasporę żydowską pozostawały w ambiwalentnych stosunkach w państwem rzymskim. Nie chodzi tu tylko i wyłącznie o prześladowania ze strony aparatu administracyjnego, ale i o stosunek, przynajmniej części chrześcijan, do rzymskiej szkoły. Sprawę komplikowało także oczywiste, już w czasach postapostolskich, zakorzenienie nowej religii w kulturze słowa, co implikowało potrzebę edukacji. Przekrój społeczny pierwszych gmin, gromadzących zwolenników nowej religii, propagowanej przez Apostołów i ich uczniów był dość specyficzny. Przewagę mieli w nich ludzie ubodzy, często niewolnicy, upatrujący poprawy swego losu w życiu wiecznym. Siłą rzeczy byli 
to ludzie, których poziom wykształcenia odbiegał od tego, jaki był reprezentowany przez zamożniejsze warstwy ludności ${ }^{1}$. Warto podkreślić, że na stosunek elit chrześcijańskich do edukacji rzymskiej, a ściślej do nauki szkolnej, zwanej doctrina, znaczący wpływ wywarł okres prześladowań religijnych, a pamiętać trzeba, że szkolnictwo w cesarstwie rzymskim było w znacznej części agendą państwa. Nauczyciele zobowiązani byli do składania egzaminów państwowych, których pomyślny wynik był niezbędny dla otrzymania licentia docendi. Rzec można, że stosunek ten nacechowany był niechęcią i brakiem zaufania dla wartości przekazywanych uczniom przez nauczycieli - pogan. Na taką postawę chrześcijan wobec szkolnictwa i nauki niewątpliwy wpływ wywarło wezwanie zawarte w Liście do Koryntian św. Pawła Apostoła: Gdzie jest mędrzec? Gdzie uczony? Gdzie badacz tego, co doczesne? Czyż nie uczynił Bóg głupstwem mądrości świata? Słowa te interpretowano jako nakaz całkowitego odwrócenia się od dorobku myśli starożytnych Greków i Rzymian².

Przeciwwagą dla antyszkolnej postawy części przynajmniej Ojców Kościoła i chrześcijańskich myślicieli był wszakże fakt, że nowa religia była religią Księgi - słowa objawionego $^{3}$. Zatem dla propagowania Dobrej Nowiny niezbędni byli ludzie potrafiący czytać. Warto zwrócić uwagę także na fakt, iż od nieomal zarania swych dziejów chrześcijaństwo posługiwało się pismem. To na piśmie, za sprawą polemik, dialogów, traktatów czy wreszcie listów trwała wymiana poglądów między poszczególnymi gminami chrześcijańskimi. Zresztą, wzorując się na tradycji żydowskiej, a początkowo mocno się z nią identyfikując (przynajmniej do końca I w.), chrześcijańskie wspólnoty w Syrii, Egipcie, Armenii tworzyły szkoły wyznaniowe ${ }^{4}$.

Istotą problemu, przynajmniej jeśli chodzi o dyskusję nad problemem czy dzieci chrześcijan powinny uczęszczać do rzymskiej szkoły, był związek literatury i kultury grecko-rzymskiej z religią pogańską. Był to problem natury moralnej tak dla dzieci, ich rodziców, jak i dla nauczycieli. Nie można też zapominać, że z punktu widzenia Rzymu, chrześcijanie byli ludźmi bezbożnymi, jawili się wręcz jako ateiści - tak widział to choćby Celsus. Nauczyciel - chrześcijanin, jeśli chciał dalej wykonywać swój zawód, zmuszony był do posługiwania się tekstami nawiązującymi do pogańskiej teologii, nie mógł ograniczyć się tylko do przekazywania sztuki czytania i pisania. Tertulian opowiadał się ok. 160 r. w traktacie $O$ bałwochwalstwie za zaprzestaniem działalności nauczycielskiej przez chrześcijan, natomiast potwierdzał, że nie ma nic zdrożnego w tym, że chrześcijanie uczyli się $\mathrm{w}$ szkole ${ }^{5}$. Zezwolenie to nie miało zresztą $\mathrm{w}$ praktyce większego znaczenia, jako że w tym okresie chrzest przyjmowali przede wszystkim dorośli, którzy już wcześniej zdobyli wykształcenie. Tertulian stwierdzał ponadto: Jak możemy odrzucić nauki świeckie, bez których jednak nie można zrozumieć nauk bożych? - - Możliwe wydaje

${ }^{1}$ Zob.: É. Trocmé, Pierwsze kroki chrześcijaństwa, Kraków 2004, s. 44-149.

2 J. Mirewicz SJ, Wspóttwórcy i wychowawcy Europy, Kraków 1983, s. 14.

${ }^{3}$ Szerzej zob. M. Simon, Cywilizacja wczesnego chrześcijaństwa I-IV w., Warszawa 1979.

${ }^{4}$ W. Myszor, Europa - pierwotne chrześcijaństwo. Idee i życie spoteczne chrześcijan (II i III wiek), Warszawa 1999/2000, s. 213.

${ }^{5}$ Ibidem, s. 213 i n. 
się, że wierni będa się uczyć literatury, a nie będa nauczać. Inne jest uzasadnienie dla uczenia się, a inne dla nauczania ${ }^{6}$.

W praktyce jednak, co należy mocno w tym miejscu podkreślić, obowiązywał wówczas niemal powszechny zwyczaj kształcenia dzieci chrześcijańskich w szkołach pogańskich, którego nie zwalczali nawet najbardziej radykalni przywódcy chrześcijańscy. Ich postawa wynikała z oczywistego faktu, że szkoła rzymska stanowiła w pierwszych wiekach chrześcijaństwa jedyne źródło świeckiej wiedzy ${ }^{7}$. Nową politykę Kościoła wobec edukacji i szkolnictwa rzymskiego widać doskonale w dziełku św. Bazylego (ok. 330-379) O czytaniu autorów pogańskich, w którym ten znakomicie wykształcony pustelnik wskazywał co prawda na szereg niebezpieczeństw tkwiących w studiowaniu literatury pogańskiej, traktował ją jednak przede wszystkim jako świadectwo dziedzictwa przeszłości, które należy znać ${ }^{8}$. Szkoły chrześcijańskie powstawały jedynie tam, gdzie istniały gminy wyznaniowe pozostające poza granicami imperium rzymskiego, a więc w Armenii i Etiopii, ale był to proces datujący się dopiero od IV do V w.

Jednocześnie następował proces tworzenia kościelnego ustawodawstwa, który nabrał dynamiki zwłaszcza po ogłoszeniu w 313 r. tzw. edyktu mediolańskiego (nota bene był to $\mathrm{w}$ istocie reskrypt, który w praktyce przywracał sytuację chrześcijan sprzed prześladowań), w którym Konstantyn Wielki i Licyniusz ogłosili, że chrześcijanie mają prawo swobodnego wyznawania swojej religii. Ta zmiana sytuacji gmin chrześcijańskich sprzyjała tworzeniu pewnych norm prawnych, które miały swe korzenie (choć jednak niebezpośrednie) w prawie rzymskim. Wymowne jest to, że synody organizowane były podczas rad miast prowincji, a biskupi obradowali na wzór senatu rzymskiego ${ }^{9}$. Co więcej, synody i sobory zwoływali w IV w. cesarze ${ }^{10}$, którzy przewodniczyli im, bądź swoją obecnością nadawali ich postanowieniom sankcję państwową. Owocem legislacyjnym synodów były uchwalane podczas ich obrad kanony, jak nazywano począwszy od schyłku IV w. normy prawne postanowione przez sobory i synody ${ }^{11}$. Terminem canones określano wszystkie przepisy, które z ustanowienia władzy kościelnej regulują życie wspólnoty kościelnej i poszczególnych wiernych, nie przyjmując cech formalnych, zwanych leges, a które znajdowały się w zakresie prawa cywilnego ${ }^{12}$.

${ }^{6}$ Tertulian, De idolalatria, t. 10, ed. J.H. Wasznik, J.C.M. Winden, Leiden 1987, s. 38 i n.; tłum. polskie za: W. Myszor, Europa - pierwotne chrześcijaństwo, s. 219.

7 J. Skoczek, Rozwój szkolnictwa w Polsce średniowiecznej, w: Historia wychowania, red. Ł. Kurdybacha, t. 1, Warszawa 1965, s. 150.

${ }^{8}$ J. Mirewicz SJ, Wspóltwórcy i wychowawcy Europy, s. 47.

9 Ibidem, s. 68.

${ }^{10}$ Dla przykładu: synod w Arles w 314 r., zgromadzenie biskupów ,,z wszystkich ziem Zachodu”, zwołał Konstantyn Wielki, przewodniczył mu natomiast metropolita Arles, Marinius. Cesarz Teodozjusz II w listopadzie 430 r. wydał dekret o zwołaniu soboru ekumenicznego do Efezu na czerwiec 431 r. W 451 r. sobór w Nicei, przeniesiony do Chalcedonu pod Konstantynopolem odbył się pod przewodnictwem cesarza Marcjana. Zob.: Sz. Włodarski, Historia papiestwa, t. 1: do 1073 r., Warszawa 1964, s. 46-102.

11 A. Dębiński, Kościól i prawo rzymskie, s. 30-46. Zob. także: P. Hamperek, W. Góralski, Historia źródeł nauki prawa kanonicznego, Lublin 1995; J. Subera, Historia źródet i nauki prawa kanonicznego, Warszawa 1977.

12 G. Ghirlanda, Wprowadzenie do prawa kościelnego, Kraków 1996, s. 11. 
Ważną kwestią, wymagającą omówienia, jest stosunek Kościoła do potrzeby tworzenia własnej sieci szkół. Ogólnie rzec można, że chrześcijaństwo nie chciało zmieniać szkoły starożytnej ani rzymskiego wychowania, proponując w tym drugim obszarze własne wzorce. Szkoła chrześcijańska przyswoiła sobie program nauczania starożytnych, a wyodrębniony zeń zasób artes liberales miał stanowić niezbędny instrument dla zrozumienia Pisma Świętego. Temat tworzenia własnego szkolnictwa właściwie nie istniał, dopóki szkoła świecka funkcjonowała w należyty sposób. Sytuacja w tym zakresie, zupełnie dobra jeszcze w czasach św. Augustyna ${ }^{13}$ i św. Hieronima zaczęła pogarszać się gwałtownie w drugiej połowie V w. Na zachodzie imperium rzymskiego nastąpiła wówczas znacząca dezintegracja systemu szkolnego, wymuszająca odpowiednią reakcję ze strony hierarchów. Kościół instytucjonalny postawiony został przed koniecznością zapewnienia należytego wykształcenia kandydatom do stanu duchownego ${ }^{14}$. Na zachodzie Europy zaczął postępować proces upadku gospodarczego miast, skutkujący ich wyludnianiem ${ }^{15}$. Miasta nie dysponowały wówczas wystarczającymi środkami finansowymi na opłacanie nauczycieli i utrzymywanie infrastruktury szkolnej. Załamaniu uległ również system administracyjny, a skutkiem kryzysu administracji był spadek zapotrzebowania na ludzi wykształconych w sztuce retorycznej. W rezultacie, nawet w tych szkołach, które wciąż funkcjonowały, nastąpił znaczący spadek liczby słuchaczy ${ }^{16}$. Taki stan rzeczy zagrażał funkcjonowaniu Kościoła jako instytucji posługującej się pismem i zmusił jego przywódców do przedsiębrania środków zaradczych.

Wydaje się, że pierwszym aktem prawnym Kościoła dotyczącym spraw edukacji był kanon III soboru chalcedońskiego z 451 r., w którym jest mowa o duchownych ,podejmujących się opieki nad małoletnimi”, co może być sygnałem o podejmowanych wówczas działaniach edukacyjnych, choć niekoniecznie musi to oznaczać prowadzenie szkó ${ }^{17}$. Z kolei kanon XVII wspomina o parafiach wiejskich i miejskich oraz o zasadach ich tworzenia ${ }^{18}$. Wszystko wskazuje, że władze kościelne musiały w drugiej połowie V w. zmierzyć się z nową rzeczywistością na gruncie edukacyjnym, związaną z powolnym zanikiem szkolnictwa dla świeckich. W Galii odnotować można obszerne statuty synodalne, pochodzące z ok. 475 r., które regulowały m.in. kwestie nauczania, wykluczając $\mathrm{z}$ edukacji kobiety, nawet te, które określano, jako docta et sancta, a także ludzi świeckich, a nakładających ten obowiązek na duchownych ${ }^{19}$. 1993.

${ }_{13}$ Zob. S. Abt, Święty Augustyn jako pedagog, Kraków 1930; P. Brown, Augustyn z Hippony, Warszawa

${ }^{14}$ Zob. M. Banniard, Wczesne średniowiecze na Zachodzie, Warszawa 1998, s. 152 i nn.

15 J.-P. Devroey, Gospodarka, w: Zarys historii Europy. Wczesne średniowiecze od 400 do 1000 r., red. R. Mc Kitterick, Warszawa 2003, s. 131 i nn. Zob. także P. Heather, Upadek cesarstwa rzymskiego, Poznań 2007.

${ }^{16}$ I. Wood, Kultura, w: Zarys historii Europy. Wczesne średniowiecze, s. 204. Zob. także: J.M.H. Smith, Europa po Rzymie. Historia kulturowa lat 500-1000. Nowe ujęcie, Kraków 2008, s. 27 i nn.

${ }^{17}$ Dokumenty soborów powszechnych, t. 1, s. 227.

${ }^{18}$ Ibidem, s. 241.

19 Statuta ecclesiae antiqua, w: Concilia Galiae A. 314-A. 506, cura et studio C. Munier, Corpus Christianorum. Series Latina, t. CXLVIII, Turnhout 1963, art. 37, s. 172: Mulier, quamuis docta et sancta, uiros in 
Na treść ustaw kościelnych dotyczących szkolnictwa przemożny wpływ wywierały lokalne warunki, stąd też obserwować można w kolejnych stuleciach zwiększony udział ustawodawstwa synodalnego tworzonego zwłaszcza w Galii i Hiszpanii w ogólnym stanie prawa kanonicznego w sprawach edukacji. W VI w. synody często podkreślały potrzebę i konieczność kształcenia duchownych, a jednocześnie pragnęły wprowadzenia ściślejszej kontroli ze strony Kościoła na proces kształcenia duchownych oraz laików ${ }^{20}$. Synod w galijskim Reims z 511 r. wydał postanowienia dotyczące m.in. kształcenia i wychowania księży ${ }^{21}$. Potrzeba organizacji szkolnictwa widoczna jest w ustawodawstwie synodów hiszpańskich, odbywających się z reguły w Toledo. Synod toledański w 527 r. zwołany przez metropolitę Montana, z woli i za zezwoleniem króla Wizygotów Amalryka (511-531) obradował m.in. nad kanonami dotyczącymi edukacji kleryków, celibatu, wierności kapłanów wobec ich biskupów ${ }^{22}$. Znakomitym przykładem działań podejmowanych ad hoc w zakresie ustawodawczym jest decyzja podjęta w 524 r. na synodzie w Arles. Zauważono wówczas, że z powodu rosnącej liczby kościołów trzeba wyświęcić więcej duchownych, a więc i wykształcić ich ${ }^{23}$. Decyzje w kwestii edukacji kleryków podjął w 527 r. synod w Toledo ${ }^{24}$. W 529 r. synod w Vaison nakazał zakładać szkoły przy kościołach. Nauczać miał w nich ksiądz, którego zadaniem było wyuczenie dzieci sylabizowania abecadła, pisania na tabliczkach i atramentem na pergaminie oraz pamiętania psalmów ${ }^{25}$. Taka szkoła wystarczała, aby otrzymać święcenia kapłańskie lub objąć urząd w świeckiej lub kościelnej administracji ${ }^{26}$. Podobne postanowienia odnajdujemy w kanonach trzeciego synodu toledańskiego z $589 \mathrm{r}$.

convent docere non praesumat; art. 38, s. 172: Laicus, praesentibus clericis, nisi ipsis probantibus, docere non audeat; art. 45: omnes clerici qui ad operandum ualidi sunt, et artificiola et litteras discant.

${ }^{20}$ Np. synod odbyty w 506 r. w art. 42, Concilium Agathense, w: Concilia Galliae A. 314-A. 506, s. $210-211$.

${ }^{21}$ Concilium Aurelianense, w: Concilia aevi Merovingici, recensuit F. Maassen, MGH, Legum sectio III: Concilia, t. I, Hannoverae 1893. Zob.: B. Kumor, Historia Kościoła, t. 2: Wczesne średniowiecze chrześcijańskie, wyd. II zm., Lublin 2005, s. 12.

${ }_{22}$ Słownik wczesnochrześcijańskiego piśmiennictwa, red. J.M. Szymusiak, M. Starowiejski SJ, Poznań 1971, s. 623; P. Riché, Edukacja i kultura w Europie Zachodniej (VI-VIII w.), Warszawa 1995, s. 138.; B. Kumor, Historia Kościoła, t. 2, s. 21.

${ }^{23}$ Tamen quia crescente ecclesiarum numero necesse est nobis plures clericos ordinare. Cyt. za: P. Riché, Edukacja i kultura w Europie Zachodniej (VI-VIII w.), Warszawa 1995, s. 109.

${ }^{24}$ Kanon 1: De his quos voluntas parentum a primis infantiae annis clericatus officio emancipavit statuimus observandum ut mox cum detonsi vel ministerio lectorum contraditi fuerint in domo ecclesiae sub episcopali praesentia a praepositio sibi debeant eruditi. At ubi octavum decimum aetatis suae compleverint annum coram totius cleri plebisque conspectus voluntas eorum de expetando conjugio ab episcopo perscrutetur. Zob.: P. Riché, Edukacja i kultura, s. 138; M. Banniard, Wczesne średniowiecze na Zachodzie, Warszawa 1998, s. 152; J.M. Szymusiak SJ, M. Starowiejski, Słownik wczesnochrześcijańskiego piśmiennictwa, Poznań 1971, s. 623 .

${ }^{25}$ Hoc enim placuit ut omnes presbyteri qui sunt in parochiis constituti secundum consuetudinem quam per totam Italiam satis salubriter teneri cognovimus juniores lectores quantoscumque sine uxoribus habuerint secundum in domo ubi ipsi habitare videntur recipiant, et eos quomodo boni patres spiritaliter nutrientes psalmos povare divinis lectionibus insistere et in lege Domini erudiro contendant ut et sibi dignos successores provideant et a Domino praemia aeterna recipiant.

${ }^{26}$ M. Miśkiewicz, Zarys kultury i archeologii Europy $w$ okresie wczesnego średniowiecza, Warszawa 2002, s. 185; M. Banniard, Geneza kultury europejskiej, s. 87. 
Program kształcenia kleryków omawiano także podczas synodu w Toledo w 633. Św. Izydor z Sewilli w kanonach 24-25 dał już całkiem konkretny regulamin wychowania i kształcenia kleryków ${ }^{27}$. Biskup Sewilli podkreślał, że duchowni powinni zaznajomić się biegle w Piśmie św., psalmach, hymnach i pieśniach, aby skuteczniej głosić nauki wiernym $^{28}$. Kanony te znalazły się także w zbiorze Anzelma z Lukki. Duchowni powinni posiadać biegłą wiedzę w Piśmie św., aby pouczać lud i utrzymywać go w wierze ${ }^{29}$. Generalnie rzecz biorąc, ustawodawstwo synodów VI w. wykreowało szkolnictwo kościelne w zakresie zarówno szkół wyższego rzędu - katedralnych, jak i na poziomie elementarnym - parafialnych. Zauważmy w tym miejscu, że szkoły kościelne tworzone były obok, a nie zamiast dotychczasowych szkół świeckich, a traktowane były raczej jako uzupełnienie braków w dostępie do edukacji niż nowy, niezależny system szkolny. Ten pierwszy etap rozwoju szkolnego ustawodawstwa kościelnego cechowała pewna lokalność i tymczasowość, a sama treść postanowień sprawia wrażenie działań podejmowanych ad hoc.

Drugi okres rozwoju kościelnego ustawodawstwa w sprawach oświaty rozpoczyna się, naszym zdaniem, wraz z reformami podejmowanymi przez karolińskich władców państwa Franków, a zmierzającymi do wzmocnienia państwa. Kościół instytucjonalny z jego wykształconymi kadrami i zasobami bibliotek traktowany był jako narzędzie w procesie reform, a Karol Wielki i jego następcy nawiązywali świadomie do dawnych prerogatyw rzymskich cesarzy. To z inicjatywy władcy podejmowane były przez hierarchów różnego rodzaju działania prawne.

W 798 r. biskup Teodulf z Orleanu wydał rozporządzenia dotyczące szkół prezbiterialnych. Ten niezwykle ważny dokument warto zacytować w całości: Niech $w$ każdej wiosce i na przedmieściach księża prowadza szkołę; jeśli wierni powierzają im dzieci, by nauczyly się czytać, niech nie odmawiaja im przyjęcia i niech je ucza z miłościa - - Kiedy księża podejmują tę funkcję, niech nie wymagaja żadnej zapłaty, a jeśli coś dostana, niech będa to tylko drobne darowizny ofiarowane przez rodziców ${ }^{30}$. W roku 801 Teodulf zarządził ponadto, aby dzieci przyjmowano do wszystkich szkół bez względu na to, czy mają zamiar poświęcić się życiu duchownemu, czy też prowadzić życie świeckie.

${ }_{27}$ Sentencia Isidori super Levitico, Collectio vetus Gallica, w: H. Mordek, Kirchenrecht und reform, s. 378; A. Bober SJ, Antologia patrystyczna, Kraków 1965, s. 407.

${ }^{28}$ De libro Ysidori officiorum II, De regulis clericorum: - - perpetuo conservare student - - postremo in doctrina, in lectionibus, psalmis, hymnis, canticis exercitio rugi incumbent. Talis enim esse debent, qui divinis cultibus sese mancipandus student, scilicet, ut, dum scientiae operam dant, doctrine gratiam populis administrant, w: Die Collectio vetus Gallica, s. 513.

29 Anselmi episcopi Luccensis, Collectio canonum, Ex Consilio Tolletano V: Ignorantia mater cunctorum errorum maxime in sacerdotibus Dei vitanda est quae docendi officium in populis susceperunt. Sacerdotes enim legere sanctas spirituas admonentur Paulo apostolo dicente ad Timotheu: Intende lectioni, exortationi dectrinae, semper permane in his. Sciant igitur sacerdotes scripturas sanctas et canones, ut omne opus eorum in predicatione et doctrina consistat, atque aedificent cunctos tam fidei scientia quam operum disciplina, s. 404. Omnis clerici, qui ad operandum validi sunt, et arteficiola et litteras discant, Canon Africanorum XLV, w: Die Collectio vetus Gallica, s. 503.

${ }^{30}$ MGH, Capitularia, ed. Brommer, s. 115-116; tłum. za: P. Riché, Chrześcijaństwo na karolińskim Zachodzie, s. 596. 
W duchu reform karolińskich, ustawodawstwo szkolne zagościło także w statutach synodu w Mantui, odbytego w 827 r., podczas którego zobowiązano biskupów, by przy wszystkich kościołach biskupich i miejskich i tam, gdzie to będzie potrzebne, ustanawiali magistrów $i$ doktorów, którzy by nauczali artes liberales $i$ sancta dogmata ${ }^{31}$. Trzeba jednak zaznaczyć, że rozporządzenie to nie przyjęło się wówczas na Półwyspie Apenińskim. Nakaz wspierania szkół przez biskupów pojawia się zresztą w tym okresie bardzo często w postanowieniach synodalnych ${ }^{32}$. Synod paryski w 829 r. przypomniał rodzicom, że dziecko trzeba posyłać do szkoły nie tylko po to, by nauczyło się czytać, lecz by opanowało podstawy wiary oraz po to, by po powrocie do domu nauczać modlitw swych rodziców, jeśli je zapomnieli3 ${ }^{33}$. Nadzór nad funkcjonowaniem szkół powierzono archidiakonom. Ten obowiązek wynikał z zaleceń synodu w Tuluzie z 844 r. oraz pouczeń biskupa Hinkmara z Reims ${ }^{34}$. Wszystkie niemal działania w sferze prawa edukacyjnego podejmowane w tym okresie wpisują się w ogólne zalecenia zawarte w królewskich zarządzeniach. Ideą karolińskiej reformy szkolnictwa, w praktyce zmierzającej do przywrócenia dawnych form i metod wychowania, było umożliwienie zdobycia wykształcenia przez świeckich. Z wielu względów beneficjentami zmian byli nieliczni arystokraci. Tym niemniej wola Karola Wielkiego za sprawą jego współpracowników, do których zaliczymy Alkuina, Hildebrandta, arcybiskupa kolońskiego (791-819), Adalharda, opata z Korbei, Richboda, opata z Lorch, Madoina, biskupa Autun i in., znalazła swe odzwierciedlenie w kościelnych normach prawnych. Teoretycznie większą siłę oddziaływania miały zapisy odnośnie co do programu szkół zawarte w Admonitio Generalis Karola Wielkiego z 789 r. Dokument ten, aczkolwiek wyszedł z kancelarii królewskiej, zasadzał swe postanowienia $\mathrm{w}$ regułach prawa kanonicznego i prawa rzymskiego, a skierowany był - w interesującym nas aspekcie - do duchowieństwa. Król Franków, w dokumencie wydanym 23 marca na walnym zgromadzeniu Franków, stanowił, że w szkołach powinno się nauczać psalmów, nota (a więc sposobu zapisywania nut), komputu (to jest reguł budowy kalendarza kościelnego) oraz gramatyki ${ }^{35}$. Podobny program kształcenia podał Karol Wielki w liście do opata klasztoru w Fuldzie, Baugulfa o potrzebie rozwijania nauki oraz rozwoju szkół przyklasztornych ${ }^{36}$. Podkreślić należy, że król Franków poruszył zagadnie-

${ }^{31}$ Cyt. za:B. Kumor, Historia Kościoła, t. 3: Złoty okres średniowiecza chrześcijańskiego, Lublin 2005, s. 113 .

${ }^{32}$ Np. cap. 5 synodu biskupa Salzburga Arna w Rispach, odprawionego w 798 r., MGH, Concilia I, nr 116, s. 234.

${ }^{33}$ Concilium Parisense a. 829, Cap. XXX: Ut ab omnibus episcopis propter honorem et utilitalitem ecclesiasticam sollicitior circa habendas scolas cura habeatur, MGH, Concilia aevi Karolini, t. II, s. 632; zob. P. Riché, Chrześcijaństwo na karolińskim Zachodzie, s. 606.

${ }^{34}$ Hinkmar z Reims, Capitula quibus de rebus magistri et decani per singulias ecclesias inquirere, et episcopo renutinare debeant, $P L$, t. 125 , kanon 11 , kol. 778.

${ }^{35}$ Admonitio generalis, w: MGH, Capitularia regum Francorum, t. I, ed. G.H. Pertz, Berlin 1835 (reprint 1991), nr 22, s. 59 i nn. Zob. W. Fałkowski, Admonitio generalis Karola Wielkiego - zapowiedź tworzenia państwa idealnego, w: Ludzie. Kościól. Wierzenia. Studia z dziejów kultury i społeczeństwa Europy Środkowej (średniowiecze - wczesna epoka nowożytna), red. W. Iwańczak, S.K. Kuczyński, Warszawa 2001, s. 419-428.

${ }^{36}$ Karoli, Epistola de litteris colendis, w: MGH, Capitularia, t. I, ed. A. Boretius, Hannover 1883; zob. także: L. Wallach, Charlemagne's De litteris colendis and Alcuin, „Speculum” 26 (1951), nr 2, s. 288-305; 
nie programu szkolnego, nakazując, by był on realizowany przy każdym biskupstwie i każdym klasztorze. Ponadto w miejscach nauczania powinno się gromadzić starannie poprawione księgi ${ }^{37}$. Nie można też pominąć faktu, że tłem powstania Epistola de litteris colendis było szkolenie misjonarzy na potrzeby rozrastającego się imperium, rozwój szkolnictwa służyć miał zatem interesom państwa ${ }^{38}$. Oba akty miały za zadanie ustalenie kanonu minimalnych wymagań stawianych duchowieństwu świeckiemu i zakonnemu na terenie imperium ${ }^{39}$.

W omawianych powyżej aktach prawnych władzy świeckiej odbija się znakomicie ówczesna tendencja do przenikania się działań ze strony władców i ze strony Kościoła. Pod wpływem modelu władcy, wypracowanego w okresie karolińskim, a nawiązującego przecież wyraźnie do ideałów antycznych, poszczególni królowie, czując się patronami Kościoła na terenie władztw, powierzonych ich przez Boga w akcie namaszczenia poprzedzającego koronację, współuczestniczyli w działaniach prawodawczych. Takowe działania podejmował Alfred Wielki (871-899), starający się o podniesienie umiejętności czytania i pisania we własnym języku wśród świeckich - co musiało przecież wymagać zgody czynników kościelnych. Król pragnął również, aby najzdolniejsi wśród młodzieży kształcili się w znajomości łaciny, w celu zasilenia szeregów duchowieństwa ${ }^{40}$.

W IX w. dało się też zauważyć zainteresowanie Kościoła rozwojem szkolnictwa katedralnego. Od czasów Eugeniusza II (824-827), kolejni papieże ponawiali dekrety nakazujące biskupom prowadzenie szkół katedralnych. Zorganizowanie szkoły nie było w tym okresie zawirowań politycznych rzeczą prostą, wymagało bowiem zaangażowania środków materialnych, odpowiedniej obsady personalnej oraz biblioteki.

Kolejny etap rozwoju szkolonego ustawodawstwa kościelnego związany był z reformą gregoriańską i tzw. renesansem XII w., a zarazem stanowił odpowiedź na rozwój miast i powstanie uniwersytetów. Podstawowe hasła reformy gregoriańskiej związane były z ideą powrotu do Kościoła z czasów apostolskich, wolnego od wpływu państwa, czy szerzej - osób świeckich. Reforma może być traktowana jako reakcja Kościoła na transformację feudalną, przemiany miejskie i ekonomiczne, zapoczątkowane w XI w., a jej istota polegała na egzekwowaniu statutów i norm istniejących w Kościele, często od stuleci. Normy te były jednak rozproszone i niejednokrotnie sprzeczne ze sobą. Konieczność ich uporządkowania legła u podstaw rozwoju prawa kanonicznego. Wiek XII przyniósł także jakościową zmianę w pedagogice za sprawą „odkrycia” dziecka i potrzeb wieku dziecięcego - obok rózgi w wychowaniu dzieci przyznano rolę uczuciu, czułości i atmosferze zaufania między dorosłymi i dziećmi. W tym też okresie pojawiła się prag-

W. Fałkowski, Admonitio generalis Karola Wielkiego, s. 420.

${ }^{37}$ MGH, Capitularia regnum Francorum, I, s. 60.

38 E. Ewig, Das Zeitalter Karls des Großen, s. 100.

${ }^{39}$ A. Kijewska, Edukacja karolińska, w: Czasy katedr - czasy uniwersytetów. Źródła jedności narodów Europy, red. W. Sajdek, Lublin 2005, s. 170.

${ }^{40}$ Zob. A. Pieniądz-Skrzypczak, Ad imitationem eius quaedam instituere providimus capitula ... Działalność prawodawcza a kształtowanie się wizerunku władcy w księstwie Benewentu w VIII-IX wieku, w: Monarchia $w$ średniowieczu. Władza nad ludźmi, władza nad terytorium. Studia ofiarowane Profesorowi Henrykowi Samsonowiczowi, red. J. Pysiak, A. Pieniądz-Skrzypek, M.R. Pauk, Warszawa-Kraków 2002, s. 73-96. 
matyczna piśmienność - umiejętność pisania i czytania stała się wówczas niezbędnym elementem życia codziennego ${ }^{41}$. Zwiększone potrzeby edukacyjne mieszczan były z kolei przyczyną powolnego przejmowania przez samorządy miast praw patronatu nad miejskimi kościołami parafialnymi oraz istniejącymi przy nich szkołami. Zjawisko to stało się widoczne szczególnie w XIII w., niemniej już w analizowanym przez nas okresie widoczne były pierwsze jego symptomy. Ta nowa dla władz duchownych sytuacja domagała się uregulowań prawnych. W nowej sytuacji znalazły się szkoły kolegiackie, które, konkurując ze szkolnictwem parafialnym, w XII i XIII w. oferowały naukę wszystkim chętnym.

Przemiany sposobu widzenia świata i formowanie się nowych form nauczania - uniwersytetów wzbudziły należyte zainteresowanie ze strony władz kościelnych, a uwidoczniło się w tematyce obrad wielkich soborów reformatorskich, które odbyły się w rzymskiej bazylice San Giovanni in Laterano.

Sobór Laterański II, obradujący w dniach 2-17 kwietnia 1139 r. przy współudziale 500 hierarchów podjął istotne z punktu widzenia poruszanej przez nas tematyki decyzje, ograniczające pole naukowych zainteresowań zakonników i kanoników regularnych. Co może wydać się dziwnym, zakazano wówczas duchownym studiowania przedmiotów świeckich ${ }^{42}$. Płynie stąd wniosek, że takowe przedmioty - prawo rzymskie i medycyna zostały uznane za domenę świata profanum, oraz, że świeccy zdobywali wiedzę z tego zakresu, choć pod kontrolą Kościoła. Był to istotny sygnał oderwania się Kościoła od spraw świeckich, choć jeszcze wielokrotnie pojawiać się będą zakazy podejmowania studiów prawniczych przez członków kleru.

Sobór laterański III (1179) zabrał głos w kwestii wydawania zgody na nauczanie (licentia docendi), co było początkiem działań zmierzających do uregulowania zasad nadawania stopni naukowych na uniwersytetach ${ }^{43}$. Zwracają naszą uwagę kanon III (Quales debeant esse qui eligendi sunt ad regimen ecclesiae) oraz, zwłaszcza, kanon XVIII - Ut prelati provideant magistris scholarum necessaria $)^{44}$. Pierwszy z nich zwraca uwagę, że od kandydatów na duchownych oczekuje się odpowiedniego wykształcenia, dotyczy to zwłaszcza biskupów ${ }^{45}$. Z kolei kanon XVIII zobowiązał biskupów, by przy każdym kościele katedralnym powołać magistra, którego zadaniem było nauczanie za darmo kleryków, ale też uczniów świeckich. Decyzja ta zagwarantowała, przynajmniej de iure, środki na utrzymanie nauczycieli i zapewniła na przyszłość trwały byt wszystkim

${ }^{41}$ E. Potkowski, Moc księgi - przykład św. Bonifacego, w: Scriptura, custos, memoriae. Prace historyczne, red. D. Zydorek, Poznań 2001, s. 203-204.

${ }^{42}$ Dokumenty soborów powszechnych, t. II, s. 147, kanon IX: Ut monachi et regulares canonici leges temporales et medicinam non discant.

${ }^{43}$ Zob. szerzej: A.B. Cobban, The Medieval Universities. Their Development and Organization, Oxford 1975.

44 Dokumenty Soborów Powszechnych, t. II, s. 171 i nn.

${ }^{45}$ Dokumenty soborów powszechnych, t. II, s. 170: Cum in sacris ordinibus et ministeriis ecclesiasticis, et aetatis maturitas et morum gravitas et scientia litterarum sit inquirenda, multo forties haec in episcopo oporet inquiri, qui ad curam positus aliorum, in se ipso debet ostendere qualiter alios in domo Domini oporteat conversari. 
szkołom katedralnym. Trzeba tu jednak zaznaczyć, że w praktyce szkoły katedralne rozpoczęły swoją działalność w skali całej chrześcijańskiej Europy dopiero w początkach XIII w.

Sobór laterański IV (1215) poruszył wiele istotnych kwestii w sprawach szeroko rozumianej edukacji ${ }^{46}$. Ojcowie soborowi w kanonie XI De magistris scholasticis nakazali, by w kapitułach katedralnych lub kolegiackich wyznaczono beneficjum dla teologa, który jako lektor teologii ma nauczać duszpasterstwa duchownych i wykładać im sacra pagina oraz głosić kazania. Rola pedagogiczna owych teologów jest trudna do przecenienia, a wynika to chociażby z faktu przygotowywania przez nich zbiorów kazań głoszonych następnie dla szerokiego kręgu wiernych ${ }^{47}$. W cytowanym kanonie zauważono ponadto, że wielu pragnących się uczyć nie może tego czynić ze względu na brak środków materialnych, jak i osób, które mogłyby uczyćc ${ }^{48}$. W tej sytuacji postanowiono, że szkoły powinny powstać nie tylko $w$ każdym kościele katedralnym, ale także $w$ innych posiadajacych wystarczajace środki. Zatrudniani w nich nauczycieli mieli w miarę swoich możliwości bezpłatnie nauczać kleryków tych i innych kościołów gramatyki oraz innych przedmiotów $w^{49}$.

W XIV w. nastąpił wzrost zasięgu kultury piśmiennej, pojawiły się biblioteki, również prywatne, kwitła twórczość literacka. Taka atmosfera sprzyjała procesowi alfabetyzacji, zwielokrotnieniu liczby uczniów w szkołach i studentów na uniwersytetach. Władze kościelne musiały odnaleźć się w nowej sytuacji, grożącej utratą monopolu w zakresie nauczania. Szczególnie skomplikowaną jawi się sytuacja szkół parafialnych w miastach. Jak zauważyliśmy wcześniej, już w XII w., początkowo w Italii i w Niemczech, szkoły szeroko otworzyły swe podwoje dla mieszczan, kupców oraz urzędników, którzy uczyli się czytania, pisania, rachunków itp. Z czasem nastąpił gwałtowny rozwój szkolnictwa miejskiego, które, co podkreśla literatura przedmiotu, było względnie luźno związane z organizacją kościelną. Działo się to ze względu na odmienne potrzeby kulturalno-oświatowe mieszczan, które tylko częściowo zaspokajane były przez obowiązujący w szkołach program nauczania. Nie bez znaczenia było też odmienne pojmowanie wielu kwestii tyczących np. sensu życia, różnice w mentalności mieszczaństwa, objawiające się przecież w kulturze mieszczańskiej afirmującej życie poprzez zabawę, postawę humanistyczną, co Kościół przyjmował bez szczególnego entuzjazmu, a co było przyczyną częstych konfliktów miast z władzami kościelnymi. Niektóre aspekty działań ustawodawczych podejmowanych w poszczególnych metropoliach zostaną poddane analizie

\footnotetext{
${ }^{46}$ Zagadnienia te omówiłem uprzednio w pracacy: Ustawodawstwo szkolne soborów od XII do pierwszej połowy XIV w. i początki jego recepcji w średniowiecznej Polsce - zarys problemu, „Biuletyn Historii Wychowania" 23 (2007), s. 7-19.

47 Zob. K. Bracha, Teolog - intelektualista i duszpasterz w spoleczeństwie średniowiecznym, w: Kolory i struktury średniowiecza, pod red. W. Fałkowskiego, Warszawa 2004, s. 136-154; idem, Wokót tysogórskich kolekcji kazań z XV w. przypisywanych Piotrowi z Miłosławia. W kręgu małżéstwa i rodziny, w: Klasztor na Świętym Krzyżu w polskiej kulturze narodowej, pod red. D. Olszewskiego i R. Gryz, Kielce 2000.

${ }^{48}$ Quia nonnulis propter inopiam et legendi studium et opportunitas proficiendi subtrahitur. Dokumenty Soborów Powszechnych, t. II, s. 246.

${ }^{49}$ Ibidem, s. 247.
} 
w końcowej części artykułu. W dalszym jednak ciągu kwestie kluczowe dla kościelnego szkolnictwa były przedmiotem troski hierarchów uczestniczących w soborach powszechnych.

Sobór w Vienne (1312) w kanonie XXIV nakazał utworzenie na uniwersytetach paryskim, oksfordzkim, bolońskim oraz w Salamance lektoratów języka hebrajskiego, arabskiego i chaldejskiego. O wystarczające wynagrodzenie dla lektorów zadbać mieli w przypadku Paryża, król Francji, w Oksfordzie natomiast: władze uniwersytetu, klasztory, kapituły, konwenty, kolegia duchownych, a więc w praktyce instytucje delegujące studentów do nauki wskazanych języków ${ }^{50}$. Podobne lektoraty powinny też funkcjonować przy Kurii Rzymskiej. Ponadto w pismach soborowych, zredagowanych przez papieża Jana XXII, znalazły się postanowienia dotyczące nauczania wiernych przez kaznodziejów z zakonów dominikańskiego i franciszkańskiego, konkurujących w tym względzie z klerem parafialnym ${ }^{51}$.

W ustawodawstwie soboru bazylejskiego (1431-1445) zauważymy podkreślenie wagi zwoływania corocznych synodów diecezjalnych, a także regularnego odbywania synodów prowincjonalnych, podczas których miano pouczać duchownych w istotnych sprawach, dotyczących zapewne także i edukacji ${ }^{52}$. Sobór postanowił także o utworzeniu szkół kształcących misjonarzy oraz o ustanowieniu odpowiednich stypendiów dla uczących się ${ }^{53}$. Dalsza część analizowanego dekretu stanowiła o niedopuszczaniu Żydów do stanowisk nauczycielskich w szkołach ${ }^{54}$.

Swoistym podsumowaniem późnośredniowiecznego ustawodawstwa soborowego w sprawach szkolnictwa były kanony soboru laterańskiego V (1512-1517), odbywającego się $\mathrm{w}$ atmosferze dominacji nowych prądów intelektualnych, a zarazem w przeddzień reformacji. Sobór nakazał mianowicie tworzenie szkół elementarnych (parafialnych), aby uczono w nich bezpłatnie gramatyki, retoryki, prawd wiary, śpiewów kościelnych, liturgii i modlitw.

${ }^{50}$ Ut igitur peritia linguarum - - per instructionis efficaciam obtineri, hoc sacro approbante concilio scholas in subscriptarum linguarum generibus, ubicunque Romanam curiam residere contigerit, nec hoc in Parisiensi et Oxoniensi, Bononiensi, et Salamantino studiis providimus erigendas, statuentes ut in quolibet locorum ipsorum teneantur viri catholici, sufficientem habentes Hebraicae, Arabicae et Chaldaeae linguarum notitiam, duo videlicet uniuscuiusque linguae periti, qui scholas regant inibi, et libros de linguis ipsis in Latinum fideliter transferantes, alios linguas ipsas solicite deceant earumque peritiam studiosa" etc., Dokumenty soborów powszechnych, t. II, s. 582.

51 Sobór w Vienne, dekret 10. 5, w: Dokumenty soborów powszechnych, t. II, s. 551. Tematyka ustawodawstwa zakonnego wykracza poza przyjęte ramy tematyczne, wymaga z uwagi na swoją obszerność osobnego omówienia.

${ }^{52}$ Postea legantur statuta provincialia et synodalia, et inter alia aliquis compendiosus tractatus, docens quomodo sacramenta ministrari debeant, et alia utila pro instructione sacerdotum, w: Dokumenty soborów powszechnych, t. III, s. 320.

${ }^{53}$ - - rectores ipsorum studiorum inter alia, quae in assumptione rectoratus iurent, hoc etiam addi volumus, operam se pro ipsius constitutionis observatione daturos - - in quibus provinciarum huiusmodi studia constituta sunt, omnio disponantur, ut hi, qui praedictas linguas doctui sunt, stypendia debita percipere voleant, w: Dokumenty soborów powszechnych, t. III, s. 346.

${ }^{54}$ Ibidem, s. 347. 
Zainteresowanie sprawami szkolnictwa przejawiali poszczególni papieże, i poczynając od Grzegorza wspierali je za sprawą stosownych aktów prawnych. Papież Grzegorz Wielki (540-604) polecał w swych zarządzeniach nauczać w szkołach kościelnych śpiewu, czytania i pisania w języku łacińskim. Wcześniej, jeśli papiestwo zabierało głos w sprawach wychowania i edukacji świeckich, to dotyczył on raczej łagodności w wychowaniu dzieci. W V w. przypominał o umiłowaniu Chrystusa do dzieci, traktowanych przezeń jako wzór niewinności, papież Leon Wielki ${ }^{55}$. Powiedzieć trzeba przy tym, że papież przeciwstawiał się pewnej tradycji rygorystycznego wychowania propagowanej przez pisarzy chrześcijańskich, np. św. Ambrożego ${ }^{56}$.

Papież Eugeniusz II (824-827), pod wyraźnym wpływem karolińskich wzorów oświatowych polecił w roku 826, aby w każdej diecezji zakładano szkoły. Polecił także przyjmować do szkół klasztornych także tych chłopców, którzy nie deklarowali chęci wstąpienia do zakonu ${ }^{57}$. Zwraca zwłaszcza uwage passus: polecamy, aby w każdej siedzibie biskupiej $i$ winnych miejscach byli mianowani $w$ razie potrzeby magistrowie i doktorowie dla nauczania młodych chłopców gramatyki i sztuk wyzwolonych, ponieważ dzięki nim łatwiej zrozumieć boskie przykazania $i$ wyjaśnić je innym ${ }^{58}$. Także papież Leon IV wydał zarządzenie o podobnej treści. Mianowicie, w roku 853 nakazał zakładać szkoły elementarne także w parafiach. Ustawa ta realnie przyczyniła się do wzrostu liczby szkół na terenie Italii, miała jednak jedynie lokalne znaczenie, nie stając się wówczas normą prawa powszechnego.

W wyniku reformy gregoriańskiej, dekrety papieskie uzyskały tę samą moc prawną co statuty soborowe. Były istotnym źródłem prawa kościelnego. Poszczególni papieże wydawali dekrety z różną częstotliwością. Wyróżniał się wśród nich niewątpliwie Aleksander III, który w okresie swego pontyfikatu (1159-1181) wydał ok. 700 dekretów ${ }^{59}$.

${ }_{55}$ Amat Christus infantiam, quam primum et animo suscepit et corpore. Amat Christus infantiam humilitatis magistram, innocentiae regulam, mansuetudinis formam. Amat Christus infantiam, ad quam majorum dirigit mores, ad quam senum reducit aetates et eos ad suum inclinat exemplum, quos ad regnum sublimat aeternum, Leon Wielki, Sermones, XXXVII, cap. 3, w: Sancti Leonis Magni, Opera Omnia, t. 1, Patrologia Latina, t. LIV, Paris 1881, s. 258-259.

56 Ambroży powiadał: Pedagodzy uchodza za przykrych, ostrych i ucią̇liwych, bo budza postrach biciem, bo nie pozwalaja na swawolę, bo domagaja się karności, bo trzymaja w ryzach dziecięce umysty, aby nie byly zbyt wybujałe, kręujac je groza. Ta właśnie surowość poprawia dzieci tak, że staja się uczciwe, trzeźwe, wstrzemięźliwe, bardziej im idzie o pochwały niż o zabawy, Św. Ambroży, Hexameron, w: Pisma starochrześcijańskich pisarzy, t. IV, Warszawa 1969, s. 204. W podobnym tonie wypowiadał się także Jan Chryzostom (zm. 407) w rozprawie O próżności i o wychowaniu dzieci.

${ }^{57}$ Kanon 34: De scolis reparandis pro studio litterarum, synod rzymski 826 r.: De quibusdam locis ad nos refertur non magistros neque curam inveriri pro studio litterarum. Iderico in universis episcopiis subiectisque plebibus et aliis locis, in quibus necessitas occurrerit, omnio cura et diligentia habeatur, ut magistri et doctores constituantur, qui studia litterarum liberaliumque atrium ac sancta habentes dogmata, assiduae doceant, quia in his maximae divina manifestantur atque declarantur mandata, w: MGH, Concilia, t. II: Concilia aevi Karollini, ed. A. Werminghoff, Hannoverae-Lipsiae 1916, s. 581. Na temat kształcenia zarówno duchownych jak i świeckich zob.: Capitula admonitionis ab Eugenio II proposita (synod rzymski, 826 r.), ibidem, s. 556-557.

58 Thumacznie za: Historia wychowania, t. 1, s. 188.

59 P. Landau, Kanonistische Ergänzungen zur Germania und Bohemia Pontificia. Päpstliche Dekretalen an Emfänger im Reich zwischen 1140 und 1198, w: Sacri canones servandi sunt. Ius canonicum et status ecclesiae saeculis XIII-XV, ed. P. Krafl, Praha 2008, s. 242. 
Papież przyznał Kościołowi wyłączne prawo kontroli nauczania we wszystkich szkołach i wymagania od nauczycieli zezwolenia na wykonywanie zawodu, wydawanego przez scholastyków kapitulnych. Aleksander III zaznaczał, że zezwolenia te miały być wydawane bezpłatnie, często jednak dochodziło w tym zakresie do nadużyć. Papież dwukrotnie: w 1160 i 1170 r. zagroził surowymi karami za pobieranie opłat przy wydawaniu licentia docendi ${ }^{60}$.

Zwraca szczególną uwagę pismo papieża Aleksandra III z 20 października 1170-1172 r., wprowadzające określenie licentia docendi ${ }^{61}$. Przywilej jego nadawania został tu jasno określony i wpłynął znacząco na rozwój uniwersytetów. W praktyce papież przyznał Kościołowi prawo kontroli nauczania we wszystkich szkołach i wymagania od nauczycieli zezwolenia na prowadzenie swej działalności ze strony scholastyków kapitulnych. Aleksander III w zarządzeniach z lat 1160 i 1170 zaznaczał, że zezwolenia na nauczanie powinny być wydawane bezpłatnie i groził surowymi karami za łamanie tegoż nakazu, co sugeruje, że dochodziło w tej sprawie do licznych nadużyć62.

Dekrety papieża Grzegorza IX (1227-1241) z 1234 r. odnosiły się do kościołów parafialnych, nakładając na ich rządców obowiązek prowadzenia szkół oraz nauczania wiernych: presbyter habens populum debet habere clericum, qui secum cantet et aliis hic expressis eum iuvet, ut quisque presbyter, qui plebem regit, clericum habeat, qui secum cantet, et epistolam et lectionem legat, et qui possit scholas tenere, et monere suos parochianos, ut filios ad fidem discendam mittant ad ecclesiam, quos ipse cum omni castitate erudiat $^{63}$. Dekret ten powtarza wcześniejsze akty prawne, sygnalizując wolę papiestwa odnośnie co do prowadzenia masowego szkolnictwa parafialnego. Z drugiej jednak strony jest to jednocześnie świadectwo trudności w realizacji założeń soboru laterańskiego IV. Warto raz jeszcze podkreślić tu znaczenie wspomnianego zbioru kanonicznego, składającego się z ok. 2000 paragrafów, a stanowiącego aż do 1918 r. podstawowy korpus prawa kanonicznego ${ }^{64}$.

Około 1300 r. Wilhelm Durrand Młodszy podsumował działania papieży w tym zakresie w następujący sposób: Biskupi winni wyznaczać magistrów w kościołach katedralnych i głównych kościołach parafialnych, by bez opłaty uczyli ubogich studentów - a dziesiąta część wszystkich kościelnych beneficjów--należy przekazać ubogim mistrzom na wydziałach uniwersyteckich, dzięki nim bowiem Kościót Boży dostapi oświecenia ${ }^{65}$.

W roku 1339 papież Benedykt XII wydał bullę Ad decorem ecclesiae, w której zobowiązał przełożonych klasztorów w całej chrześcijańskiej Europie do wysyłania na studia przynajmniej dwóch zakonników z każdego klasztoru. Papież ten wydał także szereg

${ }^{60}$ Historia wychowania, t. I, red. Ł. Kurdybacha, Warszawa 1967, s. 192.

${ }^{61}$ Aleksander III, Epistola et privilegia 87, w: PL, t. 200, s. 741.

${ }^{62}$ Historia wychowania, t., 1, s. 191-192.

${ }^{63}$ Corpus Juris Canonici, ed. E. Friedberg, t. 2, Leiden 1881, szp. 449, Dekret III, tit. 1, cap. III.

${ }^{64}$ W 1918 r. opracowano Kodeks Prawa Kanonicznego.

${ }^{65}$ Wilhelm Durrand Młodszy, De modo generali concilii celebrandi, 2, 4, 16, w: Tractatus universi juris, duce et auspicje Gregorio XIIII, t. XIII, Venetiis 1585, s. 156; cyt. polski za: J.H. Mundy, Europa średniowieczna 1150-1309, Warszawa 2001, s. 309. 
dokumentów regulujących sprawy kształcenia w poszczególnych zakonach, co jednak wykracza poza przyjęty tu zakres tematyczny. W późniejszym okresie, wobec osłabienia pozycji papieży, zwłaszcza w okresie tzw. niewoli awiniońskiej, ich działalność ustawodawcza osłabła, a dotyczyła głównie spraw uniwersytetów.

W kolejnych stuleciach episkopaty poszczególnych prowincji kościelnych w reakcji na bieżące problemy dokonywały zmian ustawodawczych. Nie sposób tu omówić wszystkich postanowień, stąd przedstawimy wybrane pomniki ustawodawstwa dotyczącego szkolnictwa metropolii gnieźnieńskiej i wybranych, sąsiadujących z nią arcybiskupstw ${ }^{66}$. Kościoły lokalne wspierane były i stymulowanie w zakresie akcji ustawodawczej za sprawą legatów papieskich, a w późniejszym okresie stałych nuncjuszy apostolskich, którzy dbali o należytą recepcję postanowień prawa powszechnego na terenie poszczególnych diecezji ${ }^{67}$. Przepisy prawa wpływały w znaczącym stopniu na kształtowanie się sieci szkół ${ }^{68}$. Co ciekawe, dokonana kwerenda prawodawstwa diecezji sąsiadujących z polską prowincją kościelną wykazała bardzo niewielkie w ich treści zainteresowanie sprawami edukacji. W niemieckich diecezjach tematy szkolnictwa parafialnego pojawiają się w ustawodawstwie synodalnym arcybiskupa Kolonii Engelberta II, który zabiegał intensywnie w 1270 r. o dynamiczny rozwój szkół w swojej diecezji ${ }^{69}$ oraz biskupa Reinberna (1279-1297) z 1283 r. ${ }^{70} \mathrm{~W}$ ustawodawstwie diecezji praskiej pierwszym zapisem tyczącym się stricte szkolnictwa był statut dziewiąty synodu odbytego 18 października 1390 r. dotyczący braków kadrowych wśród pomocniczego personelu w szkołach diecezji praskiej ${ }^{71}$. Drugi ślad reakcji czeskiego episkopatu na problemy w szkołach pochodzi z roku 1404, a dotyczy zjawiska wędrownych bakałarzy i scholarów ${ }^{72}$. Kilka lat później pojawił się statut mający na celu zwalczanie szerzących się wśród czeskich uczniów i nauczycieli oraz profesorów i studentów uniwersytetu praskiego poglądów Wi-

${ }^{66}$ Zob. szerzej: K. Ratajczak, Edukacyjne aspekty ustawodawstwa Kościoła w Polsce średniowiecznej, w: Szkoła polska od średniowiecza do XX wieku między tradycja a innowacja, pod red. I. Szybiak, A. Fijałkowskiego, J. Kamińskiej przy współpracy K. Buczek, Warszawa 2010, s. 19-32.

${ }^{67}$ Literaturę do tego zagadnienia podaję w pracy: K. Ratajczak, Legaci apostolscy w wiekach średnich i ich rola w przyjmowaniu partykularnego ustawodawstwa kościelnego przez Kościót polski - aspekty edukacyjne, „Biuletyn Historii Wychowania” 26 (2010) [wyd. 2011], s. 7-17.

${ }^{68}$ Zob. przykładowo: K. Ratajczak, XIII wiek-stulecie przełomu w dziejach średniowiecznego szkolnictwa w Polsce, „Biuletyn Historii Wychowania” 25 (2009), Poznań 2010, s. 7-20; idem, Przyczyny powstania i rozwój sieci szkół kościelnych $w$ średniowiecznej Wielkopolsce, w: Z dziejów polskiej kultury $i$ oświaty od średniowiecza do początków XX wieku, red. K. Jakubiak, T. Maliszewski, Kraków 2010, s. 165-180. Tu dalsza literatura.

${ }^{69}$ W. Hartmann, Kirche und Kirchenrecht um 900. Die Bedeutung der spätkarolingischen Zeit für Tradition und Innovation im kirchlichen Recht, Hannover 2008, s. 490.

${ }^{70}$ H. Flachenecker, Das beständige Bemühen und Reform. Zu Synoden und Synodalstatuten in den fränkichen Bistümern des 14./15. Jahrhunderts, w: Partikularsynoden im späten Mittelalter, hrsg. N. Kruppa, L. Zygner, Göttingen 2006 [Veröffentlichungen des Max-Planck-Instituts für Geschichte, Band 219, Studien zur Germania Sacra Band 29], s. 62-63.

${ }^{71}$ Item in scolis non teneant nisi honestos socios, w: Pražské synody a koncily přdhusitské doby, ed. J.V. Polc, Z. Hledíková, Praha 2002, s. 254.

${ }^{72}$ Ibidem, s. 270: Item mandat omnibus clericis vagabundis et discolis sub pena excommunicationis eterne et carcerali, ut infra mensem exeant de dyocesi et civitate et de sede etc. 
klefa. Jego książki miały zostać wycofane z obiegu i złożone w skarbcu katedralnym w Pradze ${ }^{73}$.

W diecezjach polskich wzrost zainteresowania sprawami szkolnictwa widać wyraźnie w drugiej połowie XIII w., co stanowi odpowiedź na przemiany kulturowe związane z kolonizacją na prawie niemieckim, oraz w XV w., w związku z problemami wynikającymi ze znacznego wzrostu liczby szkół, co związane było z obniżeniem jakości kadr nauczających i poziomu samego nauczania ${ }^{74}$. Nie bez znaczenia było też nasilenie zjawiska migracji uczniowskich, częściowo pozostające w związku z husycyzmem w Cze$\operatorname{chach}^{75}$. Okres niepokojów skłaniał niektórych do bezprawnego nabywania tytułów naukowych, którymi kandydaci m.in. na posady nauczycielskie maskowali swe nieuctwo i nieudolność. Z takimi kandydatami walczyła za pomocą odpowiednich postanowień (z roku 1476) diecezja wrocławska ${ }^{76}$. Biskup i kapituła przywiązywała także dużą wagę do należytego wykształcenia kanoników, zobowiązując ich do powiadamiania jej przez kanoników-studentów o każdorazowym wznowieniu lub przerwaniu studiów na wskazanych uniwersytetach ${ }^{77}$. Uchwalono również przepisy mówiące o warunkach uzyskania stypendium naukowego ${ }^{78}$.

W 1285 r. w obronie języka polskiego wystąpił stanowczo arcybiskup Jakub Świnka (1283-1314) na synodzie łęczyckim ${ }^{79}$. Zgodnie ze statutem wydanym przez arcybiskupa, znajomość polskiego była istotnym kryterium przy obsadzaniu stanowisk nauczyciel$\operatorname{skich}^{80}$. Jedynie tacy kapłani i kierownicy szkół, którzy znali dobrze język polski i potrafili w nim objaśniać autorów łacińskich, powoływani byli na odpowiednie godności ${ }^{81}$. Reakcja arcybiskupa była odpowiedzią na gwałtowny wzrost liczby niemieckiego kleru, zwłaszcza w nowo lokowanych miastach śląskich, w których organizowano szkoły niemieckojęzyczne. Swoistym echem walki toczonej w ostatnich dziesięcioleciach XIII w.

73 Statut 2 synodu praskiego z 16 czerwca 1410, w: Pražské synody a koncily přdhusitské doby, s. 291. W statucie 6 (s. 294) wyliczono teksty Wiklefa zakazane jako lektury dla studentów, jako księgi heretyckie.

${ }^{74}$ Ogólne wprowadzenie do tematyki zob.: P. Kałwa, Rys historyczny prowincjonalnego ustawodawstwa synodalnego w Polsce przedrozbiorowej, w: Księga pamiatkowa ku czci J.E.X. biskupa Mariana Leona Fulmana, cz. 1: Wydzialy kościelne, Lublin 1939, s. 126-155; J. Sawicki, Ze studiów nad synodami diecezji wroctawskiej w XIII wieku, „Prawo Kanoniczne”; 4 (1961), z. 1, s. 173-209; M. Fąka, Synody arcybiskupa Henryka Kietlicza (1199-1219), „Prawo Kanoniczne” 12 (1969), z. 3-4, s. 95-127.

${ }^{75} \mathrm{~W}$ jakimś związku z tym faktem pozostaje statut LVI De oratione scolarium kodyfikacji arcybiskupa Mikołaja Trąby.

${ }^{76}$ Synody diecezji wrocławskiej $i$ ich statuty. Na podstawie materiałów przysposobionych przy udziale A. Sabischa, oprac. J. Sawicki, Concilia Poloniae. Źródła i studia krytyczne, t. X, Wrocław 1963, s. 117.

77 Ibidem, s. 120.

78 Ibidem, s. 125.

${ }^{79}$ O działalności arcybiskupa zob.: T. Silnicki, K. Gołąb, Arcybiskup Jakub Świnka i jego epoka, Warszawa 1956; W. Karasiewicz, Jakub Świnka, arcybiskup gnieźnieński (1283-1314), Poznań 1948; B. Nowacki, Arcybiskup Jakub Świnka - budziciel i propagator polskiej świadomości narodowej, w: 1000 lat archidiecezji gnieźnieńskiej, s. 107-120.

${ }^{80} \mathrm{KDW}$, t. I, nr 551, s. 511.

81 Ibidem: - - ponatur rectores scolarium, nisi linguam Polonicam proprie sciant, et possint pueris auctores exponere in Polonica lingua. 
z napływem niemieckojęzycznych nauczycieli do szkół był statut 18 synodu w Uniejowie z 19 lutego 1326 r. $^{82}$

W ciągu XV w. poszczególne diecezje wchodzące w skład metropolii gnieźnieńskiej podczas synodów starały się rozwiązać lokalne problemy. Synod diecezji wrocławskiej z 1406 r. skupił się m.in. na doborze odpowiedniej kadry nauczającej, ograniczając udział zakonników w nauczaniu nauk świeckich ${ }^{83}$. Statuty krakowskie z 1408 r. bp Jana Szafrańca zawierały kanon 17 De magistris scholas regentiganico hucusque seruato per christianos $^{84}$. Znalazło się w nim stwierdzenie, że jedną z przyczyn upadku obyczajów stanu duchownego w diecezji krakowskiej była wielka liczba szkół w miasteczkach i wsiach, co powodowało, że uczyli w nich ,niesforni i niedouczeni bakałarze"85. Jak zauważa Stanisław Bylina, w tym samym niemal czasie, bo w 1413 r. w diecezji ołomunieckiej kategorycznie zakazano zakładania nowych szkół w parafiach wiejskich, spowodowane ubóstwem szkółek i źle wynagradzanych nauczycieli. Swą decyzję biskup ołomuniecki tłumaczył faktem, że w związku ze słabym uposażeniem nauczycieli, zajęcia tego podejmować miały się osoby zupełnie do tego nieodpowiednie. Przedstawił też opłakany stan etyczny uczniów i ich wychowawców ${ }^{86}$. Lokalny koloryt miał też statut 59 diecezji poznańskiej z synodu odprawionego przez biskupa Andrzeja Bnińskiego (1439-1479) De ovacione scholarium, zakazujący rektorom szkół hucznego świętowania wraz

\footnotetext{
${ }^{82}$ Synody diecezji wrocławskiej $i$ ich statuty, s. 349: Precipimus, quod statum felicis recordacionis domini Iacobi quondam Gniznensis archiepiscopi nostri predecessoris de non recipiendis personis alienis in terra Polonie ad beneficia ecclesiarum curam habencia et magistros ad regimen scolarum non assumendis, nisi Polonicam linguam sciant, cum inibi se utiliter exercere, ab omnibus inviolalibiliter observetur, alioquin ad quos institucis seu discosicio pertinet eorundem, si contravenerint, ingressum ecclesie fore sibi noverint interdictum.
}

${ }^{83}$ Synody diecezji wrocławskiej $i$ ich statuty, statut XIX, s. 373: Doctores quoque sive magistri, qui religiosos, habitu suo dimisso, leges vel physicam audientes, vel scienter docere in scholis suis presumpserint vel retinere, sunt excommunicati ipso facto, ut in fine dicti. Ne clerici vel monachi.

${ }^{84}$ B. Ulanowski, Statuty diecezjalne krakowskie z roku 1408, „Archiwum Komisji Historycznej AU” 5 (1889); zob. także: L. Zygner, Drei polnische Bischöfe und Juristen Peter Wysz, Jakob aus Kurdwanów, Andreas Laskarii und ihre Synodaltätigkeit in den Diözesen Krakau, Płock und Posen, w: Partikularsynoden im späten Mittelalter, s. 239-273.

${ }^{85}$ Statuty diecezjalne krakowskie z roku 1408, wyd. B. Ulanowski, w: „Archiwum Komisji Historycznej PAU”, t. V, Kraków 1889, s. 26: Item cum defectus morum et scienciarum plurium in dioecesi Cracoviensi provenit ex multiplicatione scolarum in oppidis parvis et villis, ubi nec moribus, nec in disciplinis sunt directores et sic nec in scientiis, nec in moribus, ut expedit in dictis scolis scolares instruuntur, immo pocius negliguntur et ita postea ad sacros ordines promoverunt, quare mandamus, quatinus nulli adolescentes scolares in predictis scolis, ubi nec in disciplinis, nec in moribus instruuntur, forveantur, sed pueruli, quibus ibi suppetit facultas dicendi foveantur, nisi esset magister vel baccalarius, qui salubriter eos in doctrina et in moribus dirigeret et in disciplinis confoveret. Cytat polski za: J. Fijałek, Życie i obyczaje kleru w Polsce średniowiecznej na tle ustawodawstwa synodalnego, wyd. II, Kraków 2002, s. 32 [pierwodruk, pt. Średniowieczne ustawodawstwo synodalne biskupów polskich, cz. 1: Życie i obyczaje kleru w Polsce średniowiecznej na tle ustawodawstwa synodalnego, „Rozprawy Akademii Umiejętności, Wydział Historyczno-Filozoficzny”, seria II, t. V, Kraków 1894, s. 181-239]. Zob. B. Ulanowski, Kilka uwag o statutach synodów diecezjalnych krakowskich z XIV i XV wieku, Kraków 1888, s. 26.

${ }^{86}$ S. Bylina, Statuty synodalne jako instrument chrystianizacji wsi, s. 276. 
z uczniami ${ }^{87}$. W 1456 r. odbył się w Gnieźnie synod diecezjalny, który polecił wszystkim starszym uczniom szkół parafialnych z terenu diecezji przenieść się do uniwersytetu, szkoły katedralnej lub do szkół kolegiackich, w których uczyli bakałarze i mistrzowie atrium $^{88}$. W 1477 r. ukazały się ordynacje biskupa włocławskiego Zbigniewa Oleśnickiego (1473-1480), w których zlecił rektorom szkół, by bacznie przyglądali się uczniom i informowali o przypadkach pojawienia się Czechów, skażonych grzechem husytyzmu ${ }^{89}$. Biskup podkreślił z całą mocą, że przy każdym kościele parafialnym powinna znajdować się szkoła, w której kleryk uczyć miał dobrych obyczajów, cnoty i niektórych wiadomości. Do szkół zakazano przyjmować uczniów narodowości czeskiej ${ }^{90}$.

W 1510 synod prowincjonalny piotrkowski starał się przeciwdziałać zjawisku niekontrolowanych migracji uczniowskich. Zobowiązano kierowników szkół do dokonania selekcji młodzieży i pozostawienie w szkołach tylko tych uczniów, którzy rzeczywiście chcieli się uczyć ${ }^{91}$. Do sprawy tej powrócono także w roku $1512^{92}$. Kanon 5 synodu odprawionego przez arcybiskupa Jana Łaskiego stanowił mianowicie, że włóczacych się uczniów szkolnych, którzy w ciagu trzech dni nie wróca do szkoły, pleban winien donieść oficjałowi okręgowemu, celem wymierzenia kary, w tym nawet cielesnej ${ }^{93}$. Kolejną kwestią nas interesującą było zaostrzenie wymagań stawianych kandydatom na stanowiska nauczycielskie. Na kierowników szkół katedralnych, kolegiackich i parafialnych powoływać miano ludzi wykształconych i niebudzących zastrzeżeń pod względem moralnym ${ }^{94}$.

Poczynione uwagi nie wyczerpują tematu, nie uwzględniono choćby ustawodawstwa zakonnego w zakresie szkolnictwa. Temat ten omówiliśmy w innym miejscu. Zaprezentowany materiał uwidocznił jednak punkty zwrotne w dziejach szkolnego ustawodawstwa Kościoła - od jego początków związanych z przemianami cywilizacyjnymi w cesarstwie rzymskim, a ściślej rzecz ujmując - w jego zachodniej części, która uległa stopniowej dezorganizacji. W pierwszym okresie władze kościelne na poziomie diecezji

87 Statuta diocesana ecclesie Poznaniensis, w: Synody diecezji poznańskiej i ich stauty, J. Sawicki, Concilia Poloniae. Źródta i studia krytyczne, t. VII, Poznań 1952, s. 160.

${ }^{88}$ J. Sawicki, Synody archidiecezji gnieźnieńskiej i ich statuty, Warszawa 1950 [Concilia Poloniae. Źródła i studia krytyczne, t. V], s. 62; Statuta a sinodo diocesiani Gneznensi promulgata, ed. B. Ulanowski, w: Acta capitulorum nec non iudiciorum ecclesiasticorum selecta, ed. B. Ulanowski, t. 1: Acta capitulorum gneznensis, poznaniensis et vladislaviensis (1408-1530), Kraków 1894, nr 1860, s. 422.

${ }^{89}$ Statuta diocesana Sbignei episcopi anno 1477, w: Statuta synodalia dioecesis Wladislaviensis et Pomeraniensis, ed. M. Chodyński, Warszawa 1890, s. 20-23.

${ }^{90}$ Ibidem, s. 23; zob. także: A. Karbowiak, Szkoła katedralna kujawska w wiekach średnich, „Kwartalnik Historyczny" 12 (1898), s. 763-777.

91 I. Subera, Synody prowincjonalne arcybiskupów gnieźnieńskich, Warszawa 1971, s. 98. Ostatnio datę tegoż synodu przesuwa się na początek stycznia 1511 r. - tak S. Tymosz, Szkic historyczno-biograficzny prymasa Jana Laskiego (1456-1531), w: Arcybiskup Jan Laski reformator prawa, red. S. Tymosz, Lublin 2007, s. 35 .

92 I. Subera, Synody prowincjonalne arcybiskupów gnieźnieńskich, s. 101; R. Pelczar, Ustawodawstwo synodów diecezjalnych $i$ listy pasterskie biskupów wobec szkolnictwa kościelnego dla świeckich w Polsce od XIII do XVIII wieku, „Archiwa, Biblioteki i Muzea Kościelne” 67 (1997), s. 325 i nn.

${ }_{93}$ Tekst na podstawie rękopisu nr 2834 Biblioteki Uniwersytetu Jagiellońskiego podaje I. Subera, Synody prowincjonalne, s. 80 .

94 Ibidem, s. 79. 
lub archidiecezji podejmowały decyzje mające zapobiegać bieżącym zagrożeniom dla procesu reprodukcji kadr. Etap drugi w okresie karolińskim związany jest z próbami realizacji przez władze kościelne zaleceń władzy świeckiej. Swoista symbioza, z uwagi na wspólne cele, widoczna była także w Kościele ottońskim czy też w nowo chrystianizowanych krajach Europy Środkowo-Wschodniej. Z czasem jednak, pod wpływem reformy gregoriańskiej, zaznaczała się rosnąca tendencja do tworzenia korporacyjnego szkolnictwa kościelnego dla przyszłych duchownych i zakonników, oraz z widoczną w ustawodawstwie troską o duchową głównie formację świeckich. Czwarty już, wyodrębniony przez nas etap rozwoju szkolnego ustawodawstwa kościelnego związany był z realiami ogromnych zmian społecznych, gospodarczych, jakie zaszły w Europie w XII i XIII w., a doprowadziły do nowej sytuacji na niwie oświaty w coraz to większym stopniu kontrolowanej przez osoby świeckie. Wreszcie, w późnym średniowieczu, Kościół skupił się przede wszystkim na próbach zachowania kontroli nad uniwersytetami i działaniach zmierzających do zachowania możliwie wysokiego poziomu intelektualnego duchownych. Zmuszony był też na bieżąco reagować na liczne problemy funkcjonowania szkół w poszczególnych metropoliach, które wynikały ze specyfiki rozwoju kulturalnego, ekonomicznego i społecznego Europy późnego średniowiecza. Poczynione uwagi traktować należy jako wstępny szkic, zachętę do dalszej naukowej dyskusji na ważny i wymagający pogłębionych studiów temat.

\section{Bibliografia}

\section{I. Źródła}

Admonitio generalis, w: MGH, Capitularia regum Francorum, t. I, ed. G.H. Pertz, Berlin 1835 (reprint 1991), nr 22.

Aleksander III, Epistola et privilegia 87, w: PL, t. 200.

Ambroży, Hexameron, w: Pisma starochrześcijańskich pisarzy, t. IV, Warszawa 1969.

Anselmi episcopi Luccensis, Collectio canonum, una cum collectione minore iussu institute savigniani, ed. F. Thaner, Insbruck 1906.

Concilia aevi Karolini, t. II, ed. A. Werminghoff, w: MGH, Legum sectio IV: Concilia, t. 2, Hannoverae-Lipsiae 1906.

Concilia aevi Merovingici 511-695, recensuit F. Maassen, MGH, Legum sectio III: Concilia, t. I, Hannoverae 1893.

Concilia aevi Merovingici, recensuit F. Maassen, MGH, Legum sectio III: Concilia, t. I, Hannoverae 1893.

Corpus Juris Canonici, ed. E. Friedberg, t. 2, Leiden 1881.

Die Collectio vetus Gallica. Text mit kritischen Apparat und Quellenkommentar, w: H. Mordek, Kirchenrecht und reform im Frankenreich. Die Collectio vetus Gallica. Die Älteste systematische kanonessammlung des Fränkischen Gallien. Studien und edition, Berlin-New York 1975 [Beiträge zur Geschichte und Quellenkunde des Mittelater, hrsg. v. H. Fuhrmann, Bd. 1].

Dokumenty soborów powszechnych, t. III: 1415-1445, oprac. A. Baron, H. Pietras SJ, Kraków 2007.

Dokumenty Soborów Powszechnych. Tekst grecki, taciński, polski, t. II: (869-1312), oprac. A. Baron, H. Pietras, Kraków 2002. 
Dokumenty soborów powszechnych. Tekst łaciński, grecki i polski, t. I, oprac. A. Baron, H. Pietras SJ, Kraków 2001.

Hinkmar z Reims, Capitula quibus de rebus magistri et decani per singulias ecclesias inquirere, et episcopo renutinare debeant, $P L$, t. 125.

Karoli, Epistola de litteris colendis, w: MGH, Capitularia, t. I, ed. A. Boretius, Hannover 1883

Kodeks Dyplomatyczny Wielkopolski, t. I, Poznań 1877.

Leon Wielki, Sermones, XXXVII, cap. 3 w: Sancti Leonis Magni, Opera Omnia, t. 1, Patrologia Latina, t. LIV, Paris 1881, s. 258-259.

Pražské synody a koncily přdhusitské doby, ed. J.V. Polc, Z. Hledíková, Praha 2002.

Sawicki J., Synody archidiecezji gnieźnieńskiej i ich statuty, Warszawa 1950 [Concilia Poloniae. Źródla i studia krytyczne, $t$. V].

Statuta a sinodo diocesiani Gneznensi promulgata, ed. B. Ulanowski, w: Acta capitulorum nec non iudiciorum ecclesiasticorum selecta, ed. B. Ulanowski, t. 1: Acta capitulorum gneznensis, poznaniensis et vladislaviensis (1408-1530), Kraków 1894.

Statuta diocesana ecclesie Poznaniensis, w: Synody diecezji poznańskiej i ich stauty, J. Sawicki, Concilia Poloniae. Źródta i studia krytyczne, t. VII, Poznań 1952.

Statuta diocesana Sbignei episcopi anno 1477, w: Statuta synodalia dioecesis Wladislaviensis et Pomeraniensis, ed. M. Chodyński, Warszawa 1890, s. 20-23.

Statuta ecclesiae antiqua, w: Concilia Galiae A. 314-A. 506, cura et studio C. Munier, Corpus Christianorum. Series Latina, t. CXLVIII, Turnhout 1963.

Statuty diecezjalne krakowskie z roku 1408, wyd. B. Ulanowski, „Archiwum Komisji Historycznej PAU”, t. V, Kraków 1889.

Synody diecezji wroctawskiej i ich statuty. Na podstawie materiałów przysposobionych przy udziale A. Sabischa, oprac. J. Sawicki, Concilia Poloniae. Źródła i studia krytyczne, t. X, Wrocław 1963.

Tertulian, De idolalatria, t. 10, ed. J.H. Wasznik, J.C.M. Winden, Leiden 1987.

Wilhelm Durrand Młodszy, De modo generali concilii celebrandi, 2, 4, 16, w: Tractatus universi juris, duce et auspicje Gregorio XIIII, t. XIII, Venetiis 1585.

\section{Opracowania}

Abt S., Święty Augustyn jako pedagog, Kraków 1930.

Banniard M., Wczesne średniowiecze na Zachodzie, Warszawa 1998.

Bober A. SJ, Antologia patrystyczna, Kraków 1965.

Bracha K., Teolog - intelektualista $i$ duszpasterz w społeczeństwie średniowiecznym, w: Kolory i struktury średniowiecza, pod red. W. Fałkowskiego, Warszawa 2004, s. 136-154.

Bracha K., Wokół tysogórskich kolekcji kazań z XV w. przypisywanych Piotrowi z Mitosławia. W kręgu matżeństwa i rodziny, w: Klasztor na Świętym Krzyżu w polskiej kulturze narodowej, pod red. D. Olszewskiego i R. Gryz, Kielce 2000.

Brown P., Augustyn z Hippony, Warszawa 1993.

Bylina S., Statuty synodalne jako instrument chrystianizacji wsi w późnym średniowieczu, w: Sacri synodes servandi sunt. Ius canonicum et status ecclesiae saeculis XIII-XV. Kolektivní monografie, red. P. Krafl, Praha 2008.

Cobban A.B., The Medieval Universities. Their Development and Organization, Oxford 1975.

Devroey J.-P., Gospodarka, w: Zarys historii Europy. Wczesne średniowiecze od 400 do 1000 r., red. R. Mc Kitterick, Warszawa 2003.

Fałkowski W., Admonitio generalis Karola Wielkiego - zapowiedź tworzenia państwa idealnego, w: Ludzie. Kościót. Wierzenia. Studia z dziejów kultury i społeczeństwa Europy Środkowej (średniowiecze - wczesna epoka nowożytna), red. W. Iwańczak, S.K. Kuczyński, Warszawa 2001, s. 419-428. 
Fąka M., Synody arcybiskupa Henryka Kietlicza (1199-1219), „Prawo Kanoniczne” 12 (1969), z. 3-4, s. 95-127.

Fijałek J., Życie i obyczaje kleru w Polsce średniowiecznej na tle ustawodawstwa synodalnego, wyd. II, Kraków 2002, s. 32 [pierwodruk, pt. Średniowieczne ustawodawstwo synodalne biskupów polskich, cz. 1: Życie i obyczaje kleru w Polsce średniowiecznej na tle ustawodawstwa synodalnego, „Rozprawy Akademii Umiejętności, Wydział Historyczno-Filozoficzny”, seria II, t. V, Kraków 1894, s. 181-239].

Flachenecker H., Das beständige Bemühen und Reform. Zu Synoden und Synodalstatuten in den fränkichen Bistümern des 14./15. Jahrhunderts, w: Partikularsynoden im späten Mittelalter, hrsg. N. Kruppa, L. Zygner, Göttingen 2006 [Veröffentlichungen des Max-Planck-Instituts für Geschichte, Band 219, Studien zur Germania Sacra Band 29].

Ghirlanda G., Wprowadzenie do prawa kościelnego, Kraków 1996.

Hamperek P., Góralski W., Historia źródet nauki prawa kanonicznego, Lublin 1995.

Hartmann W., Kirche und Kirchenrecht um 900. Die Bedeutung der spätkarolingischen Zeit für Tradition und Innovation im kirchlichen Recht, Hannover 2008.

Heather P., Upadek cesarstwa rzymskiego, Poznań 2007.

Historia wychowania, red. Ł. Kurdybacha, t. 1, Warszawa 1965.

Kałwa P., Rys historyczny prowincjonalnego ustawodawstwa synodalnego w Polsce przedrozbiorowej,w: Ksiega pamiatkowa ku czci J.E.X. biskupa Mariana Leona Fulmana, cz. 1: Wydziaty kościelne, Lublin 1939, s. 126-155.

Karasiewicz W., Jakub Świnka, arcybiskup gnieźnieński (1283-1314), Poznań 1948.

Karbowiak A., Szkota katedralna kujawska w wiekach średnich, „Kwartalnik Historyczny” 12 (1898), s. 763-777.

Kijewska A., Edukacja karolińska, w: Czasy katedr - czasy uniwersytetów. Źródła jedności narodów Europy, red. W. Sajdek, Lublin 2005, s. 165-180.

Kumor B., Historia Kościoła, t. 2: Wczesne średniowiecze chrześcijańskie, wyd. II zmienione, Lublin 2005.

Kumor B., Historia Kościoła, t. 3: Złoty okres średniowiecza chrześcijańskiego, Lublin 2005.

Landau P., Kanonistische Ergänzungen zur Germania und Bohemia Pontificia. Päpstliche Dekretalen an Emfänger im Reich zwischen 1140 und 1198, w: Sacri canones servandi sunt. Ius canonicum et status ecclesiae saeculis XIII-XV, ed. P. Krafl, Praha 2008.

Mirewicz J. SJ, Wspóttwórcy i wychowawcy Europy, Kraków 1983.

Miśkiewicz M., Zarys kultury i archeologii Europy w okresie wczesnego średniowiecza, Warszawa 2002.

Mundy J.H., Europa średniowieczna 1150-1309, Warszawa 2001.

Myszor W., Europa - pierwotne chrześcijaństwo. Idee i życie społeczne chrześcijan (II i III wiek), Warszawa 1999/2000.

Nowacki B., Arcybiskup Jakub Świnka - budziciel i propagator polskiej świadomości narodowej, w: 1000 lat archidiecezji gnieźnieńskiej, red. J. Strzelczyk, J. Górny, Gniezno 2000, s. 81-96.

Pelczar R., Ustawodawstwo synodów diecezjalnych i listy pasterskie biskupów wobec szkolnictwa kościelnego dla świeckich w Polsce od XIII do XVIII wieku, „Archiwa, Biblioteki i Muzea Kościelne" 67 (1997).

Pieniądz-Skrzypczak A., Ad imitationem eius quaedam instituere providimus capitula ... Działalność prawodawcza a ksztaltowanie się wizerunku władcy $w$ księstwie Benewentu $w$ VIII-IX wieku, w: Monarchia $w$ średniowieczu. Władza nad ludźmi, władza nad terytorium. Studia ofiarowane Profesorowi Henrykowi Samsonowiczowi, red. J. Pysiak, A. Pieniądz-Skrzypek, M.R. Pauk, Warszawa-Kraków 2002, s. 73-96.

Potkowski E., Moc ksiegi-przyktad św. Bonifacego, w: Scriptura, custos, memoriae. Prace historyczne, red. D. Zydorek, Poznań 2001, s. 203-204. 
Ratajczak K., Edukacyjne aspekty ustawodawstwa Kościoła w Polsce średniowiecznej, w: Szkoła polska od średniowiecza do XX wieku między tradycja a innowacja, pod red. I. Szybiak, A. Fijałkowskiego, J. Kamińskiej przy współpracy K. Buczek, Warszawa 2010, s. 19-32.

Ratajczak K., Legaci apostolscy $w$ wiekach średnich i ich rola $w$ przyjmowaniu partykularnego ustawodawstwa kościelnego przez Kościót polski - aspekty edukacyjne, „Biuletyn Historii Wychowania" 26 (2010) [wyd. 2011], s. 7-17.

Ratajczak K., Przyczyny powstania i rozwój sieci szkót kościelnych w średniowiecznej Wielkopolsce, w: Z dziejów polskiej kultury i oświaty od średniowiecza do początków XX wieku, red. K. Jakubiak, T. Maliszewski, Kraków 2010, s. 165-180.

Ratajczak K., Ustawodawstwo szkolne soborów od XII do pierwszej połowy XIV w. i początki jego recepcji $w$ średniowiecznej Polsce - zarys problemu, „Biuletyn Historii Wychowania” 23 (2007), s. 7-19.

Ratajczak K., XIII wiek - stulecie przełomu $w$ dziejach średniowiecznego szkolnictwa $w$ Polsce, „Biuletyn Historii Wychowania” 25 (2009), Poznań 2010, s. 7-20.

Riché P., Edukacja i kultura w Europie Zachodniej (VI-VIII w.), Warszawa 1995.

Sawicki J., Ze studiów nad synodami diecezji wroctawskiej w XIII wieku, „Prawo Kanoniczne”; 4 (1961), z. 1, s. 173-209.

Silnicki T., Gołąb K., Arcybiskup Jakub Świnka i jego epoka, Warszawa 1956.

Simon M., Cywilizacja wczesnego chrześcijaństwa I-IV w., Warszawa 1979.

Stownik wczesnochrześcijańskiego piśmiennictwa, red. J.M. Szymusiak, M. Starowiejski SJ, Poznań 1971.

Smith J.M.H., Europa po Rzymie. Historia kulturowa lat 500-1000. Nowe ujęcie, Kraków 2008.

Subera I., Synody prowincjonalne arcybiskupów gnieźnieńskich, Warszawa 1971.

Subera I., Historia źródet i nauki prawa kanonicznego, Warszawa 1977.

Trocmé É., Pierwsze kroki chrześcijaństwa, Kraków 2004.

Tymosz S., Szkic historyczno-biograficzny prymasa Jana Laskiego (1456-1531), w: Arcybiskup Jan Laski reformator prawa, red. S. Tymosz, Lublin 2007.

Ulanowski B., Kilka uwag o statutach synodów diecezjalnych krakowskich z XIV i XV wieku, Kraków 1888.

Wallach L., Charlemagne’s De litteris colendis and Alcuin, "Speculum" 26 (1951), nr 2, s. 288-305.

Włodarski Sz., Historia papiestwa, t. 1: do 1073 r., Warszawa 1964.

Wood I., Kultura, w: Zarys historii Europy. Wczesne średniowiecze od 400 do 1000 r., red. R. Mc Kitterick, Warszawa 2003.

Zygner L., Drei polnische Bischöfe und Juristen Peter Wysz, Jakob aus Kurdwanów, Andreas Laskarii und ihre Synodaltätigkeit in den Diözesen Krakau, Płock und Posen, w: Partikularsynoden im späten Mittelalter, s. 239-273. 